Article

\title{
Luther, Same-Sex Marriage, and the Evangelical-Lutheran Church of Finland: A Gender-Sensitive Historical Analysis
}

\author{
Sini Mikkola \\ Philosophical Faculty, School of Theology, University of Eastern Finland, P.O. Box 111, 80101 Joensuu, Finland; \\ sini.mikkola@uef.fi
}

Received: 20 December 2019; Accepted: 14 January 2020; Published: 18 January 2020

check for updates

\begin{abstract}
The issue of whether to accept same-sex relationships as marriages has been under discussion worldwide in recent years, including in the Nordic countries, such as Finland. While in other Nordic countries, the Lutheran churches officiate same-sex marriages, the Evangelical Lutheran Church of Finland (ELCF) has rejected it on theological grounds that are largely based on Reformation Era sources. This article examines the constitution committee report that was used as the basis of the decision made by the General Synod of the ELCF in May 2018 to not accept same-sex marriages. Through close reading of the report and performing content analysis from a gender-sensitive historical perspective, the article claims that the validity of the arguments of the report can be called into question, due to the lack of a hermeneutical awareness of the differences between the sixteenth and the twenty-first centuries, and the highly selective use of the sources from the Reformation Era in the document. The article concludes by pointing out that making use of the Reformation heritage in theology, instead of replicating the arguments of the sixteenth century, would have produced a theologically and historically more solid report, which could well have been in favor of extending the view on marriage in the ELCF.
\end{abstract}

Keywords: Martin Luther; Reformation Era sources; The Evangelical Lutheran Church of Finland; same-sex marriage; gender; sexuality; power; hierarchy; hermeneutical awareness; use of history

\section{Introduction}

Debate on same-sex marriage has been heated in Finland in recent years. The Parliament of Finland amended the Marriage Act in April 2016, allowing same-sex couples to either marry or alter their registered partnership into a marriage from 1 March 2017 onwards (AL 1 and 1 a §, 8.4.2016/249). This change affects the Evangelical Lutheran Church of Finland (henceforth the ELCF) profoundly, since its status as an institution joining Finnish people in marriage is historically very strong. A wedding ceremony with a pastor as the marriage officer was the only possible way to contract a marriage in Finland from 1571 (when Finland still was a part of the Kingdom of Sweden) until the beginning of 1918. The pastors of the Orthodox Church of Finland, the second largest church in the country, have been entitled to act as marriage officers since 1809 (Helander 2017, pp. 8-10). The significance of the Evangelical Lutheran wedding ceremony has remained rather considerable in Finland even in the 2010s: in 2018, 45.2\% of all marriages were contracted with a Lutheran pastor as the marriage officer (StatFin 1211).

Since the change in the Marriage Act of Finland, the question whether same-sex couples should be joined in marriage by the pastors of the ELCF has been a burning issue. From the beginning of March 2017, the situation became complex: according to the Finnish legislation, pastors as marriage officers became entitled to join same-sex couples in marriage, whereas in regard to the Church Law and 
practice, the matter is not unambiguous (for an overview on the recent history, see Ketola and Helander 2019, pp. 7-10). In the other four Nordic countries: Sweden, Denmark, Iceland, and Norway, the Lutheran churches accept same-sex marriages and officiate them (Ketola and Helander 2019, pp. 2-3).

A private member's bill ${ }^{1}$ (1/2017) to extend the conception of marriage in the ELCF to include same-sex couples was introduced to and discussed in the General Synod of the ELCF in May 2017. The General Synod, which is elected for a four-year-term at a time, is the "parliament" and thus the highest decisive body of the ELCF. It is chaired by the archbishop and assembles twice a year. For decisions of great importance-for instance, doctrinal issues such as those concerning the church's teachings about marriage as well as proposing amendments of the Church Law-a majority of three-quarters is required for the approval (KL 20:1-10 §). In regard to the private member's bill 1/2017, the Synod decided to send the proposal to the constitution committee. The committee prepared a report wherein it investigated grounds for extending the church's view of marriage and for allowing pastors to wed same-sex couples, and concluded with a proposal of a negative decision. The report was discussed in the General Synod in May 2018, and the decision of the Synod was in accordance with the proposal (See KK PTK 18.5.2018 §3, p. 33).

In this article, I will investigate the report of the constitution committee (PeVlkM 1/2018) that was used as the basis of the General Synod's decision. I will investigate the report from the viewpoint of how it uses sources from the Reformation Era in justifying the proposal of the negative decision. Informed by critical gender studies and feminist scholarship, I will especially focus on how gender is presented in relation to the institution of marriage in the document, and how it is discussed in relation to our times. The most important themes in my examination are power hierarchies, the significance of reproduction in marriage, and the use of history. I shall point out that the central problems of the document are the lack of a hermeneutical awareness of the differences between the sixteenth and the twenty-first centuries, and the highly selective use of the sources from the Reformation Era. My aim is thus not to construct a proposal for same-sex marriage but to call for a just, mindful use of historical sources. However, by the investigation made in this article, it becomes clear that the outcome of the report could also have been in favor of extending the ELCF's view on marriage.

\section{The Report, Its Sources, and Central Arguments}

The report to the General Synod was composed by the constitution committee of seventeen experts, both academic and ecclesiastical, two of whom are Reformation scholars specifically. Five of the members were not satisfied with the outcome of the work of the committee, but issued a dissenting opinion, which is attached to the report (PeVlkM 1/2018, pp. 51-54). ${ }^{2}$ Otherwise, the report consists of contextualizing the matter by discussing the private member's bill and its attachments (pp. 1-9), reporting the former discussions on marriage at the ELCF (pp. 9-16), source analysis and examination (pp. 16-50), and conclusions with the motion (pp. 50-51). The motion consists of (1) a proposal of the decision to not extend the conception of marriage in the ELCF to include same-sex couples, and (2) a proposal to ask the bishops of the ELCF to promote respectful discourse about marriage within the ELCF.

In the report, the sources of the Reformation Era-especially Martin Luther's texts-are of great importance. Namely, one third of the investigation in the report is used to evaluate and discuss the sources of the Reformation Era (PeVklM 1/2018, pp. 29-40). In regard to these, the committee aims to find out-as it itself explicates in the text—which viewpoints from history should be regarded

1 The General Synod of the ELCF includes 109 representatives: 32 of the clergy, 64 lay representatives, 11 bishops, a Sámi representative, and a representative of the Council of State. Every representative is entitled to introduce a private member's bill to the Synod. The consideration of the proposal begins with a preliminary debate, and the proposal is then sent to a committee for further examination. When the committee report is delivered, the Synod again discusses the matter.

2 The dissenting opinion notes the committee report's lack of historical awareness but concentrates mainly on modern social-ethical consideration in regard to same-sex marriage. As the dissenting opinion hardly includes historical argumentation, I have chosen to leave it outside the discussions of this article. 
as normative for the church of the present day, and which should be taken as contextual views on femininity, masculinity, and marriage, based on certain time and culture; thus not applicable for the present day (see PeVlkM 1/2018, p. 32).

The official confessional foundation of the ELCF consists of the Bible and the Book of Concord (Liber concordiae 1580) (KL 1:1 §; KJ 1:1 §). Alongside those, the Decrees of the Uppsala Synod (1593) are acknowledged as part of the foundation of the ELCF (LT evl). Accordingly, the most important sources used in the report are the Augsburg Confession (1530) and Luther's Large and Small Catechism (1529), all of which are part of the Book of Concord. Other sources, deemed significant by the committee, are Luther's Sermon on Marriage (WA 2, pp. 165-71. Ein Sermon von dem ehelichen Stand 1519), The Babylonian Captivity of the Church (WA 6, pp. 497-573. De captivitate Babylonica ecclesiae Praeludium Martini Lutheri 1520), On Married Life (WA 10.II, pp. 275-304. Vom ehelichen Leben 1522), Luther's Marriage Formula (WA 30.III, pp. 74-80. Ein Traubüchlein für die einfültigen Pfarrherr 1529), On Marriage Matters (WA 30.III, pp. 205-48. Von Ehesachen 1530), and the Genesis Commentary (WA 42; $43 ; 44$. Enarrationes in Genesin 1535-45). (PeVlkM 1/2018, p. 29) In my view, the committee could have used, for example, Luther's later Sermon on Marriage (WA 17.I, pp. 12-29. Eine predigt vom Ehestand 1525) and the Sermons on Genesis (WA 24, pp. 1b-701b. Uber das erst buch Mose 1527) as well. However, I deem the source base sufficient enough as it is.

The central arguments of the report concerning the texts of the Reformation Era, and thus the points that the committee regards as the most important, are the following:

- Marriage is imposed by God.

- The parties of marriage are man and woman.

- The most important mission of marriage is to give birth and raise children.

- Marriage is a public institution and it has to be established publicly.

- Both spouses should regard the other as a gift of God.

- Marriage is not only a gift but also a cross.

- The sexual needs of both of the spouses have to be met.

- Marriage is also a part of the social order (PeVlkM 1/2018, pp. 29-31).

From my viewpoint, the arguments can be divided into two separate groups, one containing the first three arguments, and the other the five latter ones (this is noted briefly also in Mikkola 2019a, p. 19). The first three are constitutive or primary and concern the question about the fundamentals of marriage, that is, its primary reason (God) and its central characteristics that straightforwardly follow from its nature as instituted by God: woman and man as the parties, and childbirth as its central purpose. These three constitutive arguments emerge directly from Genesis 1:27-28. The latter five arguments discuss the temporal arrangements of marriage, explaining how marital life should be viewed and executed in society. In the following two sections, I shall investigate and problematize these points that the committee has chosen.

\section{The Constitutive Elements of Marriage Revisited}

Martin Luther, as the other reformers as well, based their discussion on marriage on creation that is explicated in Genesis 1. The committee report quotes Luther's Large Catechism, wherein Luther states:

[God] has established it [marriage] before everything else and therefore created man and woman differently (as our eyes prove), not to commit knavery but to stay together, to be fruitful, beget children, feed and raise them to the honor of God. Therefore, God has most richly blessed it, more than other estates. [ ... ] Thus, marital life is no jest or presumption but a serious thing and [a matter of] Godly seriousness. For to Him all power lies in it, when one raises people that serve the world and promote [it] in God's knowledge, blessed life and 
in all virtue, and in fighting against wickedness and the devil. (WA 30.I, pp. 161-62; PeVlkM 1/2018, p. 30). ${ }^{3}$

Luther also stressed in a similar vein in his other texts, such as in On Married Life (1522) and in The Exhortation to the Teutonic Knights (1523):

For it is not a matter of free choice or decision but an essential and natural thing, that whatever is a man must have a woman and whatever is a woman must have a man.... [I]t is not a command but more than a command, namely, a divine ordinance which is not our business to hinder or ignore. (WA 10.II, p. 276)

God's word says in Genesis 1 [:27-28] and 2 [:18-25] that I am a man and you are a woman, and that we shall and must come together to multiply; no one is to prevent us from doing that, nor can anyone forbid us to do it; neither do we have it in our power to vow otherwise. We dare to act upon the basis of that word [ ... ] We were all created to do as our parents have done, to beget and rear children. This is by God laid out, commanded, and implanted in us, which is proved by our bodily members, daily emotions, and the example of the whole world. (WA 12, pp. 238, 242)

The significance of marriage becomes evident in Luther's notion of concepts "command" (eyn gepott) and "divine ordinance" (eyn gottlich werck). As Dr. Charles Cortright has noted, marriage had not only been made or established but "willed into being by the sovereign will and love of God (Cortright 2011, p. 59)." The fall (Gen. 3:1-24) did not alter the fundamental meaning of marriage for Luther but actually reinforced it: sufferings in childbirth and in making a living for the family highlighted God's original divine will (see, e.g., WA 11, p. 398; Mikkola 2017, pp. 38-39, 55, 65). During periods of the heated debate concerning the primacy of matrimony versus cloistered life, it was indeed essential for the reformers to emphasize the significance of marriage in every possible way and context (Harrington 2005; Strohl 2014, p. 370; Mikkola 2017, pp. 10, 52-57, 130 et passim.). Accordingly, Luther exempted only three different groups of eunuchs, defined in Matt. 19:12, from marriage (Stjerna 2014, p. 77; Mikkola 2017, pp. 54, 155-60).

The committee report highlights that in the texts of the Reformation Era, marriage is at the same time God's ordinance and a worldly institution. As godly ordinance (institutio divina), it is thus not an adiaphoron, that is, a non-essential and secondary matter in regard to Christian faith and life, but a peremptory part of Christian doctrine (PeVlkM 1/2018, pp. 36, 47). ${ }^{4}$ As the short summation of Luther's texts above prove, marriage was indeed not an adiaphoron for him but one of the central manifestations of God's will in a Christian's life. Thus, by reading Luther's texts and the confessional foundation of the ELCF, we can approve the report's first argument from the viewpoint of Christian doctrine in the Reformation Era and today.

In Luther's texts, the whole question of marriage as an institution was, by premise, intertwined with its proper parties (the woman and the man) and reproduction, which are the second and the third constitutive elements that are brought up in the report. The committee notes that marriage is a contract of one woman and one man, and this constitutive element cannot be abandoned. In regard to this, the report leans on a former committee report 4/2010 and explicates:

The starting point [of the committee] is the view on marriage, which is stated in the Bible and in the confessional texts of the church [i.e. the Book of Concord]. According to the faith of the church, marriage is a union of one man and one woman, imposed by God in the creation. The committee notes that the confessional texts of our church express that marriage is a substantive dimension of the creation. As such, it belongs to the social order as well.

3 All translations in the article are made by the author unless otherwise noted.

4 For analysis of marriage as divine and worldly ordinance in Luther, see (Stjerna 2014; Wiesner-Hanks 2016, p. 8). 
According to the report [4/2010], marriage is based on natural law and divine ordinance (mandatum Dei). The essential part of it [marriage] is the sexual attraction between the [two] sexes. [ ... ] The report has to state that the church cannot in this regard change its view on marriage, which is part of its faith and anthropology. (PeVlkM 1/2018, pp. 13-14, italics by the author)

According to the report, the anthropology of the ELCF contains an understanding of sexual attraction happening between - and only between-a woman and a man. In other words, it regards the anthropology of the church as purely heteronormative.

Here, one has to make one fundamental question, namely: "What or who is the church?" The committee report straightforwardly assumes that the heteronormative anthropology is something shared by the whole ELCF. If we understand "the church" as the General Synod, the highest decisive body of the ELCF, and its official stand, then the clause can be regarded as correct. If we, however, refer to "the church" as anything other than the General Synod's official stand, the generalization becomes more than problematic. Alone, the private member's bill (1/2017) about extending the conception of marriage in the ELCF is based on a more multi-faceted view of sexuality. The committee also dismisses the differing views of some of its members who issued the dissenting opinion. By the generalizing assumption of the heteronormative anthropology within the church, the committee report de facto questions the experiences and the factual human worth of part of the members of the church.

The practical actions of some bishops of the ELCF after the negative decision of the General Synod have also proven that the heteronormative anthropology does not necessarily prevail even among the authorities of the church. In the diocese of Helsinki, for instance, the chapter meeting, with bishop Teemu Laajasalo as its head, decided in October 2019 that it would not discipline those pastors who have joined same-sex couples in marriage. Even though the Church Law does not recognize same-sex marriages, the chapter meeting notes in the administration bulletin:

Because the issue is legally ambiguous [a reference to an on-going court case at the Supreme Administrative Court concerning a pastor who was sanctioned by the Oulu Diocesan Chapter for officiating same-sex marriage], the chapter regards that at this point, it is not justifiable to consider sanctions for a pastor who has acted as a marriage officer to a same-sex couple. (Hgin hpk tkli ht 30.10.2019)

Also, the bishop of the diocese of Espoo, Kaisamari Hintikka, who formerly worked as the Assistant General Secretary in the Lutheran World Federation LWF, has publicly announced their support of extending of the conception of marriage in the ELCF (K\&K 18.6.2019).

The committee thus represents heterosexual norm that cannot be generalized to the whole church. Despite this, the report justifies its heteronormativity with the third constitutive element of marriage. Namely, according to the report,

Even though reproduction and fertility can be understood in marriage in a spiritual way [reference to the fruits of the Spirit? Cf., e.g., Gal. 5:22], the literal meaning of the text is primary. The wider meaning [of reproduction] must not be used to subvert the literal one. Therefore, a marriage of a man and a woman, which implicitly targets at starting a family, has a primary status among other, different relationships. (PeVlKM 1/2018, p. 35)

The committee report thus implicitly notes that biological ability is a central cornerstone of marriage. It also acknowledges that the sources of the Reformation Era-as well as the Bible-emphasize the significance of reproduction (e.g., PeVlkM 1/2018, p. 30). However, the committee implies that it is nevertheless willing to leave the third constitutive element, giving birth and raising children, aside if necessary. In this it refers to the document Growing up together (orig. Kasvamaan yhdessä), composed by the bishops of the ELCF in 1984, and notes that in this document "the bishops warn one not to regard any of the aims of marriage as its sole purpose. A childless marriage is also a marriage (PeVlkM 1/2018, p. 10)." Here the committee's statements seem to be contradictory. The committee report regards it essential to hold on to the first two constitutive elements of marriage, and while acknowledging its 
source material's emphasis on the third one, it however does not adhere to it. Further, even though the committee remarks that reproduction is not the sole purpose or necessary to the fulfillment of marriage, it holds on to the claim that a marriage should by premise "implicitly target at starting a family". In other words, the committee presumes that when the relationship is formed by a woman and a man, this implicit target is naturally present-despite the factual outcome of the marriage.

Furthermore, in the sixteenth century, it was a common fact that not all marriages produced offspring for one reason or another. According to Luther, it could happen that the husband turned out to be impotent. Even in this case, the primacy of having offspring was a sine qua non. Therefore, the wife should, as Luther advised, contract a secret marriage with her husband's brother or closest friend, and the children born out of the second marriage should be regarded as the first husband's own. The entitlement to this kind of action was the insight that the first husband was not actually an official one since the consummation of marriage (copula carnalis) had not taken place (WA 10.II, p. 278). ${ }^{5}$ In the Late Middle Ages and in the Early Modern Era, not only marrying but also, and especially, production of offspring was closely tied to maturing, becoming an independent adult, and to the honor of the human being. Men, for example, were considered to reach maturity not only by marrying but also-and more importantly_by fathering legitimate children (Karras 2003, p. 16 et passim.).

As an institution aiming particularly at giving birth and raising children, marriage was for sixteenth-century reformers self-evidently formed by a woman and a man, solely for reasons that could be called biological. Furthermore, the discussion concerning same-sex relations was very different from our day. Of course, the concept of homosexuality was not used in the sixteenth century, neither was the term "sexuality", but same-sex relations were often referred to as sodomy. Sexual sins such as masturbation or anal sex, or other sins such as heresy could be regarded also as sodomy, and all of these were categorized among the gravest wrongdoings before God. Interestingly, sexual relations between women were not necessarily judged as sodomy but sometimes as fornication (Brundage 1987, pp. 213, 399 et passim.; Betteridge 2002, p. 3; Wiesner-Hanks 2010, pp. 108-11). The representation of one's sexuality in marriage was seen as remedy against any distorted form of sexuality.

The context of the sixteenth century is wholly different from the situation of the Finnish Protestant culture of today. For instance, marital sexuality has become a highly private issue. Also, the committee notes that a part of the reformers' ideas concerning marriage are bound to their own time. However, the report judges that "the principles of the Lutheran marriage theology that can be deduced from the Lutheran confession are still relevant and normative to the church" (PeVlkM 1/2018, p. 32). In light of this notion, the dismissal of childbirth as the central aim of marriage becomes more than ambiguous. Should one want to remain faithful to the Lutheran confessional documents, one should problematize the legitimacy of childless marriages as well. The committee did not choose to do this. Thus, the committee (and the Finnish society as a whole) considers that a marriage that does not produce offspring - whether because of choice or compulsive reasons-is a legitimate marriage, even though both the Bible and the Book of Concord stress its purpose as an institution first and foremost of procreation. The question can be posed: if the constitution committee is willing to abandon it, why does it consider the second constitutive element, the gender of the spouses, immutable? Before going deeper to this question, one has to look shortly into the five latter arguments of the committee report.

\section{Marital Relationship as Power Relationship}

In this section, I want to pay special attention to two of the latter arguments of the committee report. First of those is the notion of the spouses' value as gifts of God to each other, and the second issue will be the essentiality to fulfill sexual needs of both spouses.

5 For consummation, see, e.g., (Lind 2008; Korpiola 2009). 
The report notes that marriage between a man and a woman is an image of love between Christ and His church. By using this nuptial imagery, the report refers straightforwardly to Eph. 5:31-3 and to the marriage formula used in Wittenberg (PeVlkM 1/2018, p. 30). Further, it states that

In the Reformation Era, gender roles were emphasized more than today. In his writings, Luther joined to what seems from today's perspective a patriarchal view on women. Men took care of the public or the physically hard tasks and women concentrated on the household and the family. The man was to guide his wife, even though in a sensitive manner. On the other hand, it was emphasized that both spouses should regard the other sex as a gift of God, since God had created both the man and the woman and given equal value to them. Despite their differences and their different tasks, the spouses must not despise each other but the duty of both is to show honor, respect, and care to each other. (PeVlkM 1/2018, p. 31)

In the issue of reproduction, I raised the question of the grounds of the choices that the committee has made in the report. The issue of sixteenth-century gender relations and their significance to our day, as they are presented in the report, clarifies the selectivity of the committee.

For sixteenth-century reformers, an obvious starting point in discussing gender relations was the hierarchy between women and men. In a society with strict hierarchies between people of certain social standing, their position in the household, age, ethnicity, and so forth, the hierarchy that was constructed between the sexes was not exceptional. ${ }^{6}$ In general, the male and masculinity represented power and authority, and the female and femininity were representations of otherness and subalternity. This was justified with both the creation and fall (Thompson 1988, p. 140; Thompson 2009, pp. 514-15; Mikkola 2017, pp. 68-74). The following notion of Luther encapsulates well the power relations between women and men: "God has ordered the male person to rule, teach, and preach (WA 24, p. 107b)."

In Luther's case, the primary reason for the existence of women becomes evident in various textual contexts, such as in the following: "Women have been created for no other purpose than to serve man and to be his help in conceiving (WA BR 3, no. 766, p. 327. Transl. Susan Karant-Nunn \& Merry Wiesner-Hanks)." and "God created her [a woman's] body to be with a man, bear children and raise them, as Scripture makes clear in Genesis 1 (WA 24, p. 79b. See also WA 14, pp. 126a-7a)." Thus, the purpose of the existence of women was by premise bound to men, which denied them any independent meaning in life.

This dependency and the secondary status of women per creation alone is well in sight in the following statement of Luther, which has perhaps been one of the most often quoted passages of his texts in the gender sensitive Luther scholarship:

[t]he woman is a different creature compared to the man, and has different bodily members and a far weaker nature (membra habet dissimilia et ingenium longe infirmius). Even though Eve was an excellent creature, similar to Adam (similis Adae), who retained the image of God, that is, righteousness, wisdom, and health, she nevertheless was a woman. For as the sun is more excellent than the moon (even though the moon has the most excellent body), in a similar fashion the woman, even though she is a most beautiful work of God, is not equal to the man in glory and dignity. (WA 42 , pp. $51 b-2 b) .^{7}$

On the basis of creation, women and men were to be equally respected according to Luther. However, this mutual respect was not to disturb the gender hierarchy. Hence, women and men could

6 One excellent example of the ways to do fresh readings of the authoritative Christian texts that discuss gender relations is Dale Martin's book Sex and the Single Savior, wherein he investigates, for instance, the meaning of Paul's wording "there is no man and woman in Christ" (Gal. 3:28) by doing careful exegesis and drawing upon traditional viewpoints but at the same time making an up-to-date, queer interpretation of the passage. See (Martin 2006, pp. 77-90). See also chapter 8 for Martin's analysis of the New Testament texts from the viewpoint of their hostility towards family life.

7 For discussion on the sun and moon in Luther, see, e.g., (WA 2, p. 224; WA 9, p. 485; WA 14, p. 112b; WA 24, p. 53b); in scholarship, see, e.g., (Wunder 1998, pp. 205-6; Bell 2005, pp. 166-67). 
be equal in terms of salvation and their standing before God, but before other people, the hierarchies certainly existed, and were deemed by Luther as natural and necessary (see also Gerle 2015, p. 136; Mikkola 2017, p. 84).

Of course, the difference between women and men, or between femininity and masculinity, was often not clearly defined in practice. Men possessed characteristics that could be deemed as feminine, and vice versa. Whether one's particular way of being was, for example, considered improper or threatening, depended largely on the situation at hand (see, e.g., Mikkola 2019c). Thus, even though the idea of the hierarchical relationship between women and men could be quite clear in theory, the norms, expectations, and practices varied greatly even — and perhaps especially—in the smallest unit of society, the household. The Hausfrau, the lady of the household, had, for instance, a self-evident power over her male servants in addition to her children. In marriages of spouses whose class origin was different, and the wife was of higher estate, it was common for the wives to keep their husbands aware of the status that their origin allowed for them (MacCulloch 2003, pp. 649-50; Mikkola 2019b, p. 65).

Hence, in principal, gender relations were based on certain roles in the Reformation Era, like the committee report notes. These role expectations rested upon long-standing traditions within and on the fringes of Christianity. ${ }^{8}$ In the report, however, the committee does not take into account the variety of the practical ways of living out one's gender in the Reformation Era, which are briefly sketched in the previous paragraph. At the same time, the report also paradoxically fails to understand the gravity of the premise of gender inequality in the sixteenth century.

Even though the report notes the kefale structure of the early modern marital relationships by referring to Eph. 5:31-3, it does not explicate that the question was not only of love or devotion but also of authority and domination. The man was legally the guardian of his wife (SM 1999, pp. 79, 127; Luther notes this in, e.g., WA 15, p. 420), which reinforced the familial structure of the man as the head, or Christ, of the relationship, and the woman as the body or the church (cf. 1. Cor. 11:3). Naturally, the man's predominance over his wife was not only a privilege but also a responsibility. As Luther remarked, male guardianship meant that the husband had to love his wife as his own body (WA 17.I, p. 24). Failing to do this one way or another, he became a target of ridicule and suspicion. Thus, quite a few husbands tended to secure their position, and their honor in the eyes of others, by keeping their wives under control by means of domestic violence, which was accepted by the community, the court, and, for instance, reformers like Luther (for Luther's approving stance, see Mattox 2003, p. 56). ${ }^{9}$

From the viewpoint of gender hierarchy and guardianship, the argument of the committee report concerning the necessity to meet the sexual needs of both spouses can be questioned as well. By premise, it was expected in the sixteenth century, as earlier, that both spouses gave their bodies to each other when joined in marriage (Wiesner-Hanks 2016, p. 3). This expectation was based on Pauline view on the reciprocal giving of the bodies:

A wife does not have authority over her own body, but her husband does. In the same way, a husband doesn't have authority over his own body, but his wife does. Do not deprive each other except perhaps by mutual consent and for a time, so that you may devote yourselves to prayer. Then come together again so that Satan will not tempt you because of your lack of self-control. (1. Cor. 7:4-5)

The reformers thus based their understanding of marital sexuality especially on the first two sentences of Paul's wording (for Luther's texts, see, e.g., WA 10.II, pp. 286, 290). The peremptory nature of marital debt or duty was so serious for Luther that in 1522 he recommended divorcing-or even issuing a death penalty for-a spouse who was not willing to pay the debt (WA 10.II, pp. 289-90;

8 For studies on Reformation and gender, see, e.g., (Conrad 1999; Hendrix and Karant-Nunn 2008; Stjerna 2009, esp. pp. 213-22; Roper 2009; Wiesner-Hanks 2009).

9 For Luther's judging stance, see (WA 17.I, p. 24); for marital violence in the late medieval and early modern Europe, see, e.g., (Butler 2007; Lidman 2008). 
Mikkola 2017, pp. 100-2), a piece of advice that can hardly be found from any other reformer of the sixteenth century (Harrington 2005, p. 89). In marital sex, the question was not primarily of a voluntary act of giving pleasure to the other but of paying a binding marital debt time after time. The body, which had become the possession of the spouse at the moment of promising oneself to the other in marriage, was expected to be in the use of the new owner whenever he or she felt desire for it.

The limits of marital sex were strict, however. In the medieval penitentials, the ecclesiastical manuals composed for priests to be used in private confessions (Wiesner-Hanks 2010, p. 41), these limits were explicated, and every married Christian came to know them in the process of detailed question-answer confessional interplay, which was repeated at regular intervals. Limitations concerned certain times of the liturgical year, such as the three Lents, certain weekdays, times of day, phases of the menstrual cycle, pregnancy of the wife, and proper places and positions, among others (Brundage 1987, pp. 154-63; Mikkola 2019b, pp. 245-46). Knowing the ecclesiastical context well, Luther exhorted people not to pay attention to the restricted times. This was to the benefit of the whole human being, for more important than following the restrictions, it was to make sure that marital sex served its purpose as a remedy against sin. If the limitations were too strict, one was in danger of being governed by "the evil lust (bosser lust)" (WA 10.II, p. 292) due to the failure of letting the heat out regularly.

In his later years, especially after marrying himself in 1525, Luther also began to acknowledge the significance of pleasure as part of one's sexual life as well. In his Lectures on Genesis during the 1540s, for example, he severely disapproved a situation wherein the man sexually provoked (provocare) the woman and then frustrated her at the moment of climax (illo ipso momento eam frustrari) by onanism (WA 44, p. 317). Luther's earlier exhortations or his growing estimation of the pleasures of sex were by no means an entitlement to sexual experimentation. His later work on Genesis proves this explicitly: the men who thought that they could do anything they wanted with their wives in the bed, were horribly wrong. These men were pigs rather than honorable husbands (WA 43, p. 454).

For Luther as for other contemporary theologians, sexuality was a highly gendered topic. The difference between women and men defined the entitlement to demand marital sex from the other. Namely, since femininity was seen as passive and masculinity as active, the most obvious conclusion was that mainly the man could justifiably show his desire for sex (for this in Luther, see WA 10.II, p. 284). ${ }^{10}$ As Merry Wiesner-Hanks has aptly remarked, also the suitable position that the church officials required actually fortified gender hierarchy. The so-called missionary position with the man on the top, facing down, and the woman on the bottom, looking upward at the man, best guaranteed the conception but also reminded the spouses of the proper hierarchy between them (Wiesner-Hanks 2016, p. 3). As noted, Luther did not reject the requirements concerning proper position or place for sex, but only the restrictions to times it was allowed to be exercised.

In my view, the gendered nature of sexuality adds one layer to the discussion of giving one's body to the other. Hence, the implicit expectation in the sixteenth century was that the woman, especially, should be in the use of her husband whenever he wished (see, e.g., WA 10.II, p. 290). According to this view, since the husband was the guardian of and the authority over the wife, she could have little effect on how he used her body. This belongs, as we have to bear in mind at all times, to the level of gendered ideals that were produced discursively. Real-life relationships between couples manifested themselves in various ways, often differently from the ideals cherished by (male) authors and authorities. ${ }^{11}$ However, in the context of discussing the committee report that evaluates texts that have transmitted particularly the ideals of the sixteenth century, the idea of the woman's duty to truly be the rib of her husband is of most importance.

10 For medieval gendered dichotomies, see (Bynum 2012, pp. 151-79); for the expectation of female passivity, see (Butler 2007, p. 257 et passim.); the ideal of passivity seems to be rather permanent, bridging across time and culture, as becomes evident in, e.g., (Carlson 2009).

11 For evaluation on how the marital ideals may have effected people in practice, see (Brundage 1987, pp. 160-61; Wiesner-Hanks 2016, pp. 3-4). 
To sum up this section: many of the statements of the report of the constitution committee do not describe the society of the sixteenth century nor Luther's thinking truthfully enough. Instead, they offer a smoothed version of the reality of gender relations in the sixteenth century. For example, the patriarchal views of the reformers did not involve merely their discussions on women, as the committee report claims, but the question of their view of the whole of the human reality. In other words, patriarchalism was an inherent part of the sixteenth-century reformers' worldview and anthropology as a whole. Consequently, gender hierarchy and patriarchalism were self-evident starting points in all of their views on marriage as well.

From the viewpoint of this day, the fundamental nature of marriage-drawn from the sources of the Reformation Era-is that of a hierarchical institution that recreates and reproduces domination and oppression. Hence, if we would truly like to do justice to the texts of the Reformation, the list of the arguments of the committee report should be supplemented with two more arguments:

- Marriage is a hierarchical relationship between the guardian (the husband) and person under guardianship (the wife).

- In marriage, one has to meet expectations of the society, which are largely defined by one's body and gender, and are unambiguously heteronormative by nature.

\section{Conclusions: Marriage as a Time-Bound Institution}

My aim in this article has been to analyze the committee report 1/2018 from critical, gender-sensitive historical perspective and to discuss how the report uses the sources of the Reformation Era in justifying the proposal of the negative decision. I have especially discussed the themes of gender relations, power hierarchies, reproduction, guardianship, and domestic violence in order to prove that as an institution, marriage was seen very differently in the sixteenth century compared to our understanding of it today. This hermeneutical awareness occurs rather poorly in the committee report. Therefore, the validity of the arguments that the report makes on the basis of the sources of the Reformation Era can be heavily called into question.

In Finland, the historical burden of patriarchy and gender hierarchy has been significant alone in marital legislation. It was not before the year 1860 that it became illegal for the husband to physically discipline the wife. In 1994, rape in marriage became criminalized-until then, it was prohibited to press charges against a husband who raped his wife. Furthermore, married women have had the entitlement to work without the permission of their husbands from 1919 onwards (StatFin 2018, pp. $3-5$ ). It is, then, justified to say that the Pauline view of giving oneself wholly and unrestrictedly to the use of the other, cherished by the sixteenth century reformers, had been an essential part of the Finnish legislation until the 1990s. From today's point of view, it is hence not trivial to evaluate the theological and historical roots of institutions such as marriage. Pulling down-or holding on to-suppressing structures, like marital violence, is always a conscious choice and it necessitates knowledge on their history.

The picture that the committee report paints of gender relations in the sixteenth century could be called equality in difference. The report stresses the differing roles of women and men, and regards that the reformers' claims to treat each other respectfully and tenderly are especially worth of noticing. One can, obviously, find these emphases in texts of the Reformation Era. However, inequality, as well as the questions of power, authority, and dominance that are as much a part of the sixteenth century views concerning gender relations, are chosen to be left aside in the report, nearly unmentioned. The difference between the sixteenth century and the 2010s in the whole idea of the human being is, hence, not sufficiently taken into account. The reasons for these choices remain unclear, since the committee does not explicate the hermeneutical keys of its analyses anywhere in the report.

The report also dismisses the significance of reproduction in the sources of the Reformation Era without properly discussing and problematizing the matter. It seems that the committee validates a state of affairs-that there are childless marriages for various reasons, even because of the will of the spouses themselves-merely because childless marriages are a sort of a common practice in society. 
This state of affairs cannot be theologically justified with the Bible or with other texts that form the confessional foundation of the ELCF, but this is ignored by the committee. In addition to the silence concerning other topics highlighted above, this mode of action suggests for its part that the outcome of the report-the proposal of the decision not to extend the conception of marriage in the ELCF to include same-sex couples-has perhaps been present before the analyses have been made of the sources of the Reformation Era.

Historical research, or the use of history, is always about the choices one makes. The contents of the committee report 1/2018 consists of the choices of people who formulated it, and, should the composition of the committee have been different, the outcome of its work would most probably also be somewhat different. Our interpretations and our processes of giving a certain matter a certain meaning is an ethical matter of fact in modern historical research, and these research ethical questions should, obviously, be at the center of the theological work within the church as well. When doing theology on the basis of historical documents, the most essential question is not, at the end of the day, what the Book of Concord or Luther say about a matter or another, but what are the meanings that are given to the sixteenth-century sources by us, the modern interpreters, in regard to our own historical context.

When calling for the Lutheran churches' responsibility to re-evaluate and reform their marriage theology as the historical context changes and scientific knowledge on the human being increases, Professor Kirsi Stjerna has remarked:

Theologians are called to task to reassess what exactly is the church's role in marriage matters today and properly advise the church to do its "job," with the support of theological and anthropological perspectives that employ both the Scriptures and the scientific wisdom of the day, and to do so with compassion for the people whose lives are affected by what the church and its theologians say. (Stjerna 2014, p. 65)

Stjerna highlights three important factors that should be taken into account when doing theology: the Christian tradition, the scientific knowledge of this day in regard to, for example, the way one's sexual identity is formed, and the human dignity of all people. It seems that the constitution committee has in many ways failed to take into account the significance of these points, as I have shown in the examination.

One example of the alternative ways to use the Reformation texts in a more constructive manner is connected to the notion that I made in the former section of Luther's willingness to abandon traditional ecclesiastical norms in regard to the restricted times for marital sex. In fact, the willingness to question tradition and the status quo is the primary cause and, hence, the central cornerstone of the Reformation as phenomenon. This could have been a guideline for the constitution committee as well. Rather than repeating and replicating the circumstances of the sixteenth century, the committee could-and should-have made use of the Lutheran heritage in doing theology: by drawing upon the tradition in order to make fresh, up-to-date theological arguments.

With a deeper understanding of gender and of (Reformation) history, the constitution committee could have been able to produce a theologically and historically more solid report. It may have even been able to question its seeming premise - that now turned into its conclusion-and thereby have delivered a report without a dissenting opinion by nearly one-thirds of the committee.

Funding: This research received no external funding.

Acknowledgments: I thank the anonymous peer reviewers for their invaluable comments, which helped me to clarify my thesis and findings, and sharpen the whole of the text.

Conflicts of Interest: The author declares no conflict of interest. 


\section{References}

\section{Primary Sources}

AL. Avioliittolaki, osa I: Avioliiton solmiminen ja purkaminen [Marriage Act, Part I: Contracting and Dissolving Marriage]. Available online: https://www.finlex.fi/fi/laki/ajantasa/1929/19290234 (accessed on 5 November 2019).

Hgin hpk tkli ht. Helsingin hiippakunnan tuomiokapituli, hallintotiedote [The Administration Bulletin of the Helsinki Diocesan Chapter] 30.10.2019. Available online: https://helsinginhiippakunta.fi/tuomiokapitulinistunto-30-10-2019/ (accessed on 25 November 2019).

K\&K. Kirkko \& kaupunki [Journal Church \& the City] 18.6.2019. Available online: https: //www.kirkkojakaupunki.fi/-/-nyt-on-yhdestoista-hetki-piispat-kaisamari-hintikka-ja-teemu-laajasalotoivovat-hallinto-oikeuden-paatoksen-patistavan-kirkkoa-hyvaksymaan-samaa-suku\#8683cec3 (accessed on 10 January 2020).

KJ. Kirkkojärjestys [Church Order]. Available online: https://www.finlex.fi/fi/laki/ajantasa/1993/19931055?search\% 5Btype\%5D=pika\&search\%5Bpika\%5D=kirkkojärjestys (accessed on 26 November 2019).

KK PTK. Kirkolliskokouksen pöytäkirja [The Minutes of the General Synod] 18.5.2018. Available online: http://domus.evl.fi/ktwebbin/dbisa.dll/ktwebscr/khakhaku_tweb.htm (accessed on 5 November 2019).

KL. Kirkkolaki [Church Law]. Available online: https://www.finlex.fi/fi/laki/ajantasa/1993/19931054 (accessed on 6 November 2019).

LT evl. Luterilaiset tunnustuskirjat, Suomen evankelis-luterilainen kirkko [The Lutheran Confession of the ELCF]. Available online: http://www.tunnustuskirjat.fi (accessed on 26 November 2019).

PeVlkM 1/2018. Perustevaliokunnan mietintö 1/2018 edustaja-aloitteesta 1/2017: Kirkon avioliittokäsityksen laajentaminen [Committee Report 1/2018 about Private Member's Bill 1/2017: Extending the Church's View on Marriage]. Available online: http://domus.evl.fi/ktwebbin/dbisa.dll/ktwebscr/khakhaku_tweb.htm (accessed on 6 November 2019).

StatFin. Population, Changes in marital status. 1211 Newly married by age, order number of marriage and type of ceremony, 2006-2018. In Statistics Finland's PxWeb databases. Available online: http: //pxnet2.stat.fi/PXWeb/pxweb/en/StatFin/StatFin_vrm_ssaaty/statfin_ssaaty_pxt_1211.px/(accessed on 5 November 2019).

WA. D. Martin Luther's Werke. Kritische Gesamtausgabe. Weimar 1883-.

WA BR. D. Martin Luther's Werke. Kritische Gesamtausgabe. Briefwechsel. Weimar 1930-.

\section{Secondary Sources}

Bell, Theo M. M. A. C. 2005. Man is a Microcosmos: Adam and Eve in Luther's Lectures on Genesis (1535-1545). Concordia Theological Quarterly 69: 159-84.

Betteridge, Tom. 2002. Introduction. In Sodomy in Early Modern Europe. Edited by Tom Betteridge. Manchester and New York: Manchester University Press, pp. 1-10.

Brundage, James A. 1987. Law, Sex, and Christian Society in Medieval Europe. Chicago: The University of Chicago Press.

Butler, Sara. 2007. The Language of Abuse: Marital Violence in Later Medieval England. Leiden: Brill.

Bynum, Caroline Walker. 2012. Fragmentation and Redemption. Essays on Gender and the Human Body in Medieval Religion. New York: Zone Books. First published 1991.

Carlson, A. Cheree. 2009. The Crimes of Womanhood: Defining Femininity in a Court of Law. Urbana: University of Illinois Press.

Conrad, Anne, ed. 1999. "In Christo ist weder man noch weyb." Frauen in der Zeit der Reformation und der katholischen Reform. Münster: Aschendorff Verlag.

Cortright, Charles. 2011. "Poor Maggot-Sack that I Am": The Human Body in the Theology of Martin Luther. Ph.D. dissertation, Marquette University, Milwaukee, WI, USA.

Gerle, Elisabeth. 2015. Sinnlighetens närvaro: Luther mellan kroppskult och kroppsförakt. Stockholm: Verbum. Harrington, Joel F. 2005. Reordering Marriage and Society in Reformation Germany. Cambridge: Cambridge University Press. 
Helander, Eila. 2017. Selvitys Suomen evankelis-luterilaisen kirkon vihkioikeudesta luopumisesta ja avioliittoon vihkimisen merkityksestä kirkon identiteetille [Report on Renouncing the Right of the Evangelical Lutheran Church of Finland to Join in Marriage, and on the Significance of Joining in Marriage to the Identity of the Church]. Available online: https://evl.fi/documents/1327140/32925062/Selvitys+evankelisluterilaisen+kirkon+vihkioikeudesta+luopumisesta/ecc892c5-88dc-5475-19a7-c9bb223071f5 (accessed on 5 November 2019).

Hendrix, Scott, and Susan Karant-Nunn, eds. 2008. Masculinity in the Reformation Era. Missouri: Truman State University Press.

Karras, Ruth Mazo. 2003. From Boys to Men: Formations of Masculinity in Late Medieval Europe. Philadelphia: University of Pennsylvania Press.

Ketola, Kimmo, and Eila Helander. 2019. Same-sex marriage and the Lutheran Church in Finland: How rapid change in values and norms challenges the church and its decision-making. Zeitschrift für Religion, Gesellschaft und Politik. Available online: https://doi.org/10.1007/s41682-019-00043-8 (accessed on 25 November 2019).

Korpiola, Mia. 2009. Between Betrothal and Bedding: Marriage Formation in Sweden 1200-1600. Leiden: Brill.

Lidman, Satu. 2008. Zum Spektakel und Abscheu: Schand- und Ehrenstrafen als Mittel öffentlicher Disziplinierung in München um 1600. Frankfurt am Main: Peter Lang.

Lind, Göran. 2008. Common Law Marriage: A Legal Institution for Cohabitation. Oxford: Oxford University Press.

MacCulloch, Diarmaid. 2003. Reformation: Europe's House Divided 1490-1700. London: Allen Lane.

Martin, Dale. 2006. Sex and the Single Savior: Gender and Sexuality in Biblical Interpretation. Louisville: Westminster John Knox Press.

Mattox, Mickey. 2003. Defender of the Most Holy Matriarchs: Martin Luther's Interpretation of the Women of Genesis in the Enarrationes In Genesin, 1535-1545. Leiden: Brill.

Mikkola, Sini. 2017. "In Our Body the Scripture Becomes Fulfilled." Gendered Bodiliness and the Making of the Gender System in Martin Luther's Anthropology (1520-1530). Ph.D. dissertation, University of Helsinki, Helsinki, Finland. ISBN 978-951-51-3881-1 (Paperback); 978-951-51-3882-8 (PDF).

Mikkola, Sini. 2019a. “Toinen otetaan, toinen jätetään": Reformaation tekstien käyttö kirkolliskokouksen perustevaliokunnan mietinnössä ["One will be taken, and the other will be left behind": The Use of Reformation Texts in the Committee Report 1/2018 of the General Synod]. Vartija-lehti 1: 17-30.

Mikkola, Sini. 2019b. Rakkaat Sisaret, Riehaantuneet Rouvat: Martin Lutherin Naiset [Dear Sisters, Rampageous Ladies: Martin Luther's Women]. Helsinki: Kirjapaja.

Mikkola, Sini. 2019c. Manly Women, Feminine Men: Mere Exceptions or Signs of Inclusive Thinking? Alternative Readings of Martin Luther's Anthropology. In The Alternative Luther: Lutheran Theology from the Subaltern. Edited by Else Marie Wiberg Pedersen. Minneapolis: Fortress Press, pp. 137-56.

Roper, Lyndal. 2009. Gender and the Reformation. Archiv für Reformationsgeschichte 92: 290-302.

SM. 1999. The Saxon Mirror. A Sachsenspiegel of the Fourteenth Century. Translated by Maria Dobozy. Philadelphia: University of Pennsylvania Press.

StatFin. 2018. Sukupuolten tasa-arvo Suomessa 2018 [Gender Equality in Finland 2018]. Available online: http://www.stat.fi/tup/julkaisut/tiedostot/julkaisuluettelo/yyti_sts_201800_2018_19722_net.pdf (accessed on 22 November 2019).

Stjerna, Kirsi. 2009. Women and the Reformation. Oxford and Malden: Blackwell Publishing.

Stjerna, Kirsi. 2014. Luther on Marriage, for Gay and Straight. Seminary Ridge Review 16: 64-85.

Strohl, Jane E. 2014. Luther on Marriage, Sexuality, and the Family. In The Oxford Handbook of Martin Luther's Theology. Edited by Robert Kolb, Irene Dingel and L'ubomír Batka. Oxford: Oxford University Press, pp. 370-82.

Thompson, John L. 1988. Creata ad Imaginem Dei, Licet Secundo Gradu: Woman as the Image of God According to John Calvin. The Harvard Theological Review 81: 125-43. [CrossRef]

Thompson, John L. 2009. Rule Proved by Exceptions: The Exegesis of Paul and Women in the Sixteenth Century. In A Companion to Paul in the Reformation. Edited by R. W. Holder. Leiden and Boston: Brill, pp. 501-40.

Wiesner-Hanks, Merry. 2009. Gender and the Reformation. Archiv für Reformationsgeschichte 100: 350-65. [CrossRef]

Wiesner-Hanks, Merry. 2010. Christianity and Sexuality in the Early Modern World: Regulating Desire, Reforming Practice. Abingdon: Routledge. First published 2000. 
Wiesner-Hanks, Merry. 2016. Martin Luther on Marriage and the Family. In Oxford Research Encyclopedia of Religion. Oxford: Oxford University Press, 24p. [CrossRef]

Wunder, Heide. 1998. He is the Sun, She is the Moon: Women in Early Modern Germany. Cambridge and London: Harvard University Press. 